\title{
Budidaya Terung Ungu di Pekarangan di Desa Ciawijapura Kecamatan Susukan Lebak Kabupaten Cirebon
}

\author{
Umi Trisnaningsih $^{1 *}$, Siti Wahyuni ${ }^{1}$ dan Wachdijono ${ }^{2}$ \\ ${ }^{1}$ Program Studi Agroteknologi, Fakultas Pertanian, Universitas Swadaya Gunung Jati, Cirebon, Indonesia; \\ ${ }^{2}$ Program Studi Agribisnis, Fakultas Pertanian, Universitas Swadaya Gunung Jati, Cirebon, Indonesia
}

Diterima: 28 Maret 2021; Disetujui: 1 Mei 2021

\begin{abstract}
Abstrak
Lahan pekarangan dapat dimanfaatkan sebagai lumbung pangan keluarga. Salah satu upaya untuk mengatasi keterbatasan lahan adalah dengan budidaya di tempat terbatas (bag culture system) seperti polybag, pot atau ember bekas. Di Desa Ciawijapura, Kecamatan Susukan Lebak, Kabupaten Cirebon, terung ungu biasa dibudidayakan di lahan-lahan kering, maupun di pekarangan. Program Pengabdian Kepada Masyarakat (PKM) ini bertujuan untuk meningkatkan pengetahuan para ibu kader Tim Penggerak Pembinaan Kesejahteraan Keluarga (TP-PKK) dan anggota Kelompok Wanita Tani (KWT) Al Istiqomah tentang budidaya terung ungu secara bag culture system. Metode yang digunakan adalah pelatihan dan pendampingan. Hasil evaluasi menunjukkan terjadi peningkatan pengetahuan secara nyata antara sebelum dengan sesudah pelatihan, yaitu dari $73 \%$ ke $89 \%$ dari total nilai harapan. Para peserta dapat memahami perbedaan antara budidaya terung ungu di lahan dengan budidaya secara bag culture system.
\end{abstract}

Kata kunci: Ciawijapura; pekarangan; terung ungu

\section{The Cultivation of Purple Eggplant in Backyard, at Ciawijapura Village, Susukan Lebak Sub-District, Cirebon Regency}

\begin{abstract}
Yard land can be used as a family food barn. One of the efforts to overcome the limitations of land is by cultivating in a limited place (bag culture system) such as polybags, pots or used buckets. In Ciawijapura Village, Susukan Lebak Sub-district, Cirebon Regency, purple eggplant is commonly cultivated in dry land, as well as in yards. This Community Service Program (Pengabdian Kepada Masyarakat/PKM) is aimed at increasing the knowledge of Family Welfare Building Motivation Team (Tim Penggerak Pembinaan Kesejahteraan Keluarga/TP-PKK) cadres and members of Farmer Women Group (Kelompok Wanita Tani/KWT) Al Istiqomah about cultivating purple eggplant in a bag culture system. The methods used are training and mentoring. The evaluation results showed that there was a significant increase in knowledge between before and after the training, that is, from $73 \%$ to $89 \%$ of the total expected value. The participants were able to understand the difference between cultivating purple eggplant on land and in a bag culture system.
\end{abstract}

Keywords: backyard; Ciawijapura; purple eggplant

\footnotetext{
*Corresponding author: umitrisna@gmail.com

Cite this as: Trisnaningsih, U., Wahyuni, S., \& Wachdijono. (2021). Budidaya Terung Ungu di Pekarangan di Desa Ciawijapura Kecamatan Susukan Lebak Kabupaten Cirebon. AgriHealth: Journal of Agri-food, Nutrition and Public Health, 2(1), 39-44. doi: http://dx.doi.org/10.20961/agrihealth.v2i1.49872
} 


\section{PENDAHULUAN}

Tanaman terung merupakan salah satu jenis tanaman sayuran tropis yang telah banyak dikenal oleh masyarakat Indonesia (Umarie et al., 2019). Hampir setiap daerah di Indonesia mempunyai masakan khas dengan terung sebagai bahan utamanya. Selain digunakan sebagai sayuran segar, terung juga dapat dimanfaatkan sebagai bahan baku pembuatan manisan, dodol atau asinan (Safei et al., 2014). Kandungan serat yang tinggi pada terung memberikan pengaruh yang baik pada sistem pencernaan. Selain itu kulit terung, terutama terung ungu, diyakini baik untuk kesehatan kulit. Kandungan fitonutrien pada terung juga berpengaruh baik terhadap kesehatan otak manusia (Sahid et al., 2014).

Lahan pekarangan di Desa Ciawijapura sering dimanfaatkan untuk budidaya tanaman sayuran, termasuk terung. Namun seiring dengan perkembangan ekonomi dan jumlah penduduk, lahan pekarangan di Desa Ciawijapura cenderung menjadi sempit dan hampir tidak ada tanah yang terbuka. Oleh karena itu para ibu melakukan budidaya tanaman dalam tempat terbatas (bag culture system), seperti pot, ember bekas dan polybag. Namun demikian, mereka tidak mengetahui bahwa ada perbedaan antara budidaya di lahan terbuka dengan budidaya secara bag culture system. Akibatnya, terung yang ditanam tidak memberikan hasil seperti yang diharapkan.

Budidaya terung secara bag culture system hampir sama dengan budidaya terung di lahan terbuka. Bahan tanaman yang digunakan adalah bibit terung yang cukup umur dengan pertumbuhan yang baik serta sehat. Bibit yang akan digunakan adalah yang berumur kira-kira 30 hari setelah semai, memiliki empat daun (Alzarliani et al., 2019). Hasil penelitian menunjukkan umur bibit pindah tanam 30 hari mampu meningkatkan tinggi tanaman, jumlah daun, mempercepat umur berbunga, bobot buah per tanaman, bobot segar tanaman bagian atas, bobot kering tanaman bagian atas dan bobot kering akar (Ervina et al., 2016).

Komposisi media tanam akan berpengaruh terhadap pertumbuhan dan hasil tanaman terung pada budidaya terung secara bag culture system. Media tanam yang kaya akan bahan organik dan unsur nitrogen akan mendorong tanaman terung untuk memberikan hasil yang optimal (Waskito et al., 2017). Penambahan bahan organik ke dalam media tanaman diketahui dapat meningkatkan pertumbuhan dan hasil terung (Safei et al., 2014). Media tanam yang terdiri dari tanah, arang sekam dan pupuk kandang dengan perbandingan yang sama, memberikan pengaruh yang baik bagi pertumbuhan tanaman terung (Santosa dan Sumarni, 2016).

Agar budidaya terung di pekarangan dapat memberikan hasil yang optimal dan aman untuk dikonsumsi keluarga, maka para ibu perlu diberi tambahan pengetahuan tentang budidaya terung secara bag culture system. Bahan makanan yang aman artinya tidak atau sedikit sekali mengandung residu pestisida dan lebih banyak menggunakan bahan organik. Pengetahuan tentang budidaya terung secara bag culture system ini akan disampaikan dalam bentuk pelatihan, yang terdiri dari penyuluhan dan praktik budidaya tanaman terung. Kegiatan ini merupakan kegiatan Pengabdian Kepada Masyarakat (PKM) yang bertujuan untuk memberikan tambahan pengetahuan dan keterampilan para ibu, terutama anggota Tim Penggerak Pembinaan Kesejahteraan Keluarga (TP-PKK) dan Kelompok Wanita Tani (KWT) Al Istiqomah Desa Ciawijapura.

Diharapkan dengan mengikuti kegiatan ini, para ibu dapat tetap memanfaatkan lahan pekarangannya dengan menanam tanaman terung ungu yang ramah lingkungan walaupun secara bag culture system. Para ibu dapat memilih jenis media tanam yang sesuai dengan syarat tumbuh tanaman terung secara bag culture system, mencampurnya kemudian memelihara tanaman dan mengendalikan hama penyakit dengan menggunakan pestisida nabati.

\section{BAHAN DAN METODE}

Program PKM Budidaya Terung Ungu di Lahan Pekarangan ini dilaksanakan di Desa Ciawijapura, Kecamatan Susukan Lebak, Kabupaten Cirebon pada bulan Februari-Maret 2021. Mitra dalam program ini adalah TP-PKK Desa Ciawijapura dan KWT Al Istiqomah Desa Ciawijapura. Bahan yang digunakan dalam kegiatan ini adalah benih terung ungu kultivar Mustang 1, kompos, sekam mentah, tanah untuk media tanam (Santosa dan Sumarni, 2016), cocopeat untuk media persemaian dan pupuk NPK.

Metode yang digunakan dalam kegiatan PKM ini adalah pelatihan dan pendampingan. 
Pelatihan dilaksanakan pada tanggal 5 Februari 2021, di Balai Desa Ciawijapura. Agar dapat menerapkan protokol kesehatan, jumlah peserta dibatasi hanya 20 orang. Kegiatan pelatihan terdiri dari penyuluhan dan kemudian diikuti dengan praktik budidaya tanaman terung. Praktik budidaya berupa demplot dilakukan di Kebun Percontohan milik KWT Al Istiqomah, yang terletak di belakang Kantor Kuwu Ciawijapura. Pada saat praktik, peserta diajarkan cara menyemai benih dengan menggunakan tray dan memindahkan bibit dari tray ke polybag yang mempunyai lebar $8 \mathrm{~cm}$. Setiap polybag diisi media tanam yang terdiri dari kompos, tanah dan sekam mentah dengan perbandingan 1:3:1 $(\mathrm{v} / \mathrm{v})$. Setiap polybag diisi media tanam sebanyak $500 \mathrm{ml}$ dan ditambahkan $2 \mathrm{~g}$ pupuk NPK. Pada saat tanaman sudah cukup besar, maka akan dipindahkan lagi ke dalam polybag berukuran $15 \mathrm{~cm}$ (lebar) yang diisi dengan media tanam sebanyak 4-5 1. Pendampingan dilakukan selama tiga minggu mulai dari satu minggu setelah pelatihan. Monitoring dilakukan satu kali dalam seminggu, bersamaan dengan evaluasi kegiatan. Tujuannya adalah untuk mengetahui permasalahan yang muncul selama pemeliharaan tanaman sehingga bisa segera dicarikan solusinya.

Untuk mengetahui pengaruh program PKM terhadap pengetahuan dan keterampilan peserta dilakukan survei awal (pre-test) sebelum pelatihan dan survei akhir (post-test) pada saat monitoring terakhir. Untuk aspek pengetahuan, pertanyaan terdiri dari pengetahuan tentang jenis-jenis terung yang biasa dibudidayakan, manfaat terung, perbedaan antara budidaya dalam polybag dengan di kebun, serta pemanfaatan lahan pekarangan. Sementara untuk aspek keterampilan yang ditanyakan adalah cara membuat persemaian, cara membuat media tanam dan pemeliharaan. Data yang diperoleh dianalisis dengan menggunakan uji $\mathrm{T}$ berpasangan. Berdasarkan hasil uji $\mathrm{T}$, maka dapat diketahui apakah terjadi peningkatan skor secara nyata antara hasil survei awal dengan survei akhir.

\section{HASIL DAN PEMBAHASAN}

Pelatihan yang dilaksanakan di Balai Desa Ciawijapura diikuti oleh 20 orang peserta, termasuk Ketua TP-PKK Desa Ciawijapura, Ketua KWT Al Istiqomah dan seorang Penyuluh Pertanian Lapangan (PPL) dari BPP Lemahabang, yang juga membawahi Kecamatan Susukan Lebak (Gambar 1). Materi yang disampaikan dalam penyuluhan adalah budidaya terung ungu dalam polybag. Dalam materi penyuluhan disampaikan perbedaan antara budidaya terung di lahan terbuka dengan di polybag, terutama dalam hal media tanam dan pemeliharaan. Selain itu juga disampaikan tentang pemupukan serta pengendalian hama dan penyakit yang aman bagi lingkungan.

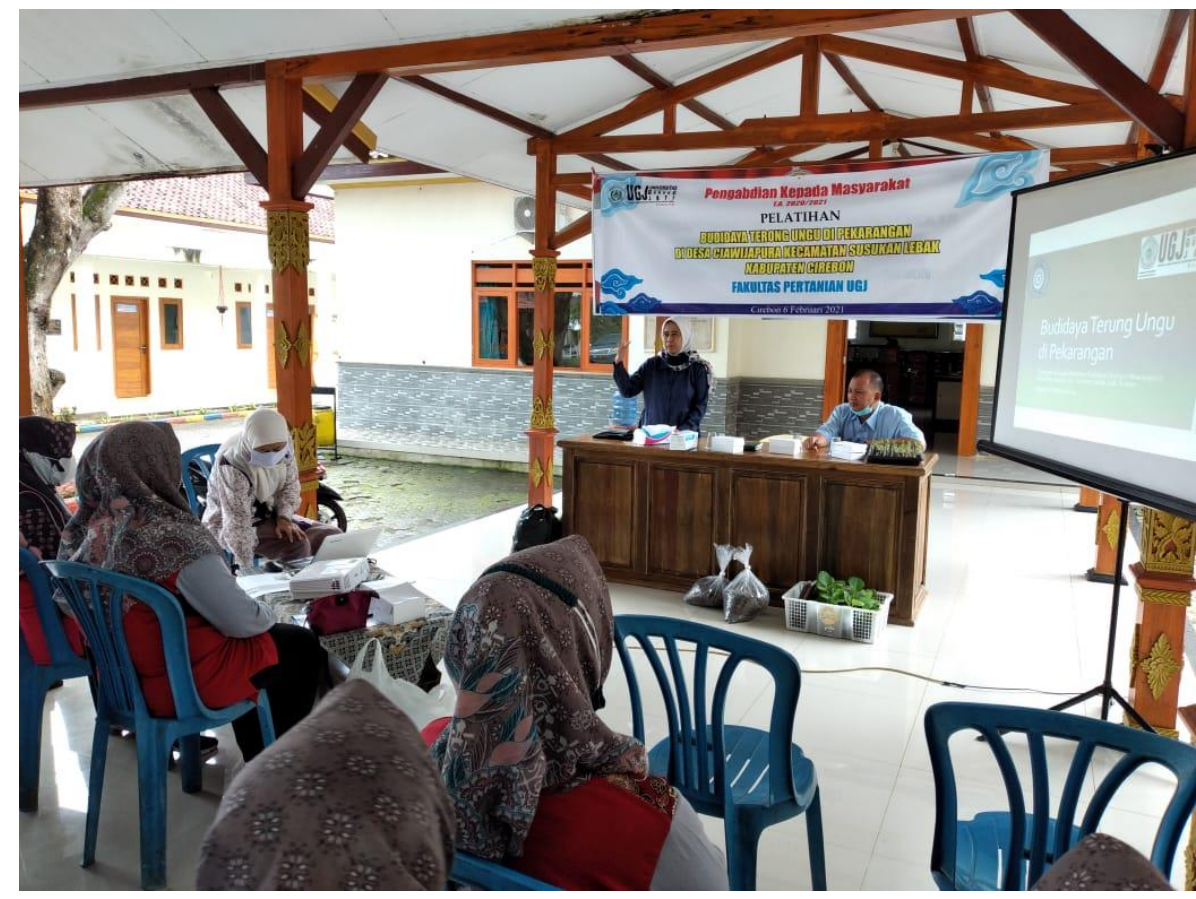

Gambar 1. Penyuluhan budidaya terung ungu di pekarangan, di Balai Desa Ciawijapura 
Pada sesi praktik budidaya tanaman terung, para peserta dilatih cara membuat persemaian dengan menggunakan cocopeat sebagai media tanam. Selain itu juga para peserta dilatih cara pindah tanam bibit terung, mulai dari persemaian, memindahkan bibit ke polybag kecil kemudian ke polybag yang lebih besar (Gambar 2). Pemilihan cocopeat sebagai media persemaian akan memudahkan ketika pindah tanam (Thoriqussalam dan Damanhuri, 2019), karena media akan tetap melekat pada bibit tanaman. Dengan demikian bibit tidak akan mengalami stres ketika ditanam di tempat lain. Cocopeat juga dapat menyimpan air dengan baik sehingga mendukung proses perkecambahan (Ramadhan et al., 2018). Proses perkecambahan dimulai dengan proses imbibisi (Miransari dan Smith, 2014). Dengan demikian, ketersediaan air dalam media tanam menjadi faktor penentu keberhasilan perkecambahan.

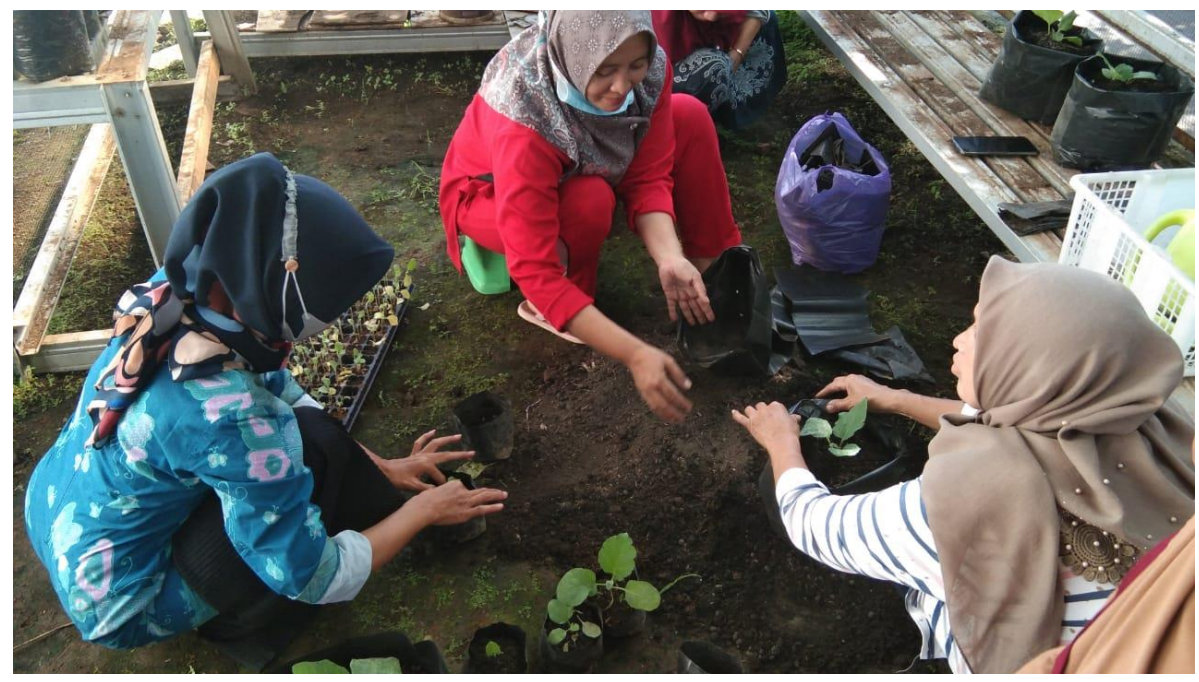

Gambar 2. Praktik memindahkan bibit dari persemaian ke polybag kecil

Bibit terung bisa dipindahkan ke polybag kecil pada umur 21 hari setelah semai (HSS) atau sudah mempunyai empat helai daun. Tanaman dalam polybag maupun persemaian hasil praktik para peserta disimpan di screen house di kebun percontohan milik KWT Al Istiqomah, yang terletak di belakang Balai Desa Ciawijapura. Pada kesempatan tersebut juga dibahas tentang teknik pemeliharaan tanaman terung ungu. Para pengurus dan anggota KWT Al Istiqomah telah terbiasa berbagi tugas dalam memelihara tanaman yang ada di kebun percontohan sehingga untuk pemeliharaan tanaman terung juga mereka berbagi tugas pemeliharaan.

Konsultasi dan pendampingan dilakukan selama tiga minggu pertama pada masa pemeliharaan. Monitoring pertama dilakukan pada tanggal 23 Maret 2021, tidak sesuai dengan jadwal yang telah disepakati. Hal ini disebabkan karena salah satu anggota Tim PKM ada yang terpapar Covid-19 sehingga monitoring ditunda sampai kondisi dinyatakan aman. Pada monitoring pertama ditemukan adanya serangan kutu putih dan cendawan jelaga. Hal ini disebabkan karena kondisi screen house cukup lembab, sehingga baik kutu maupun jamur bisa berkembang biak.

Pengendalian dilakukan secara manual, yaitu membersihkan bagian tanaman yang terserang dengan air dan kemudian tanaman disemprot dengan larutan ekstrak bawang putih, agar tidak diserang kembali oleh kutu putih. Untuk mengurangi kelembaban di sekitar tanaman, maka jarak antar polybag diperlebar menjadi sekitar $25 \mathrm{~cm}$ dan jumlah tanaman di dalam screen house dikurangi.

Hasil uji T berpasangan dengan menggunakan program SPSS, menunjukkan bahwa terjadi peningkatan pengetahuan yang nyata tentang budidaya terung ungu di pekarangan, antara sebelum dengan sesudah mengikuti pelatihan, dengan tingkat signifikansi 0,002>0,05 (data tidak disajikan). Hal ini disebabkan antara lain karena materi yang disajikan disampaikan dengan bahasa yang mudah dipahami dan disertai dengan praktik budidaya yang membantu peserta untuk lebih memahami materi yang disampaikan. Selain itu 
tingkat pengetahuan awal para peserta telah cukup tinggi (Gambar 3), yaitu $73 \%$ dari total nilai harapan. Setelah pelatihan tingkat pengetahuan meningkat menjadi $89 \%$ dari total nilai harapan. Para peserta pelatihan, yang sebagian besar merupakan anggota KWT Al Istiqomah telah terbiasa bercocok tanam di lahan terbuka sehingga memiliki pengalaman dalam bercocok tanam. Pengalaman tersebut merupakan pengetahuan awal yang mendorong mereka untuk memiliki ketertarikan terhadap materi pelatihan yang diberikan.

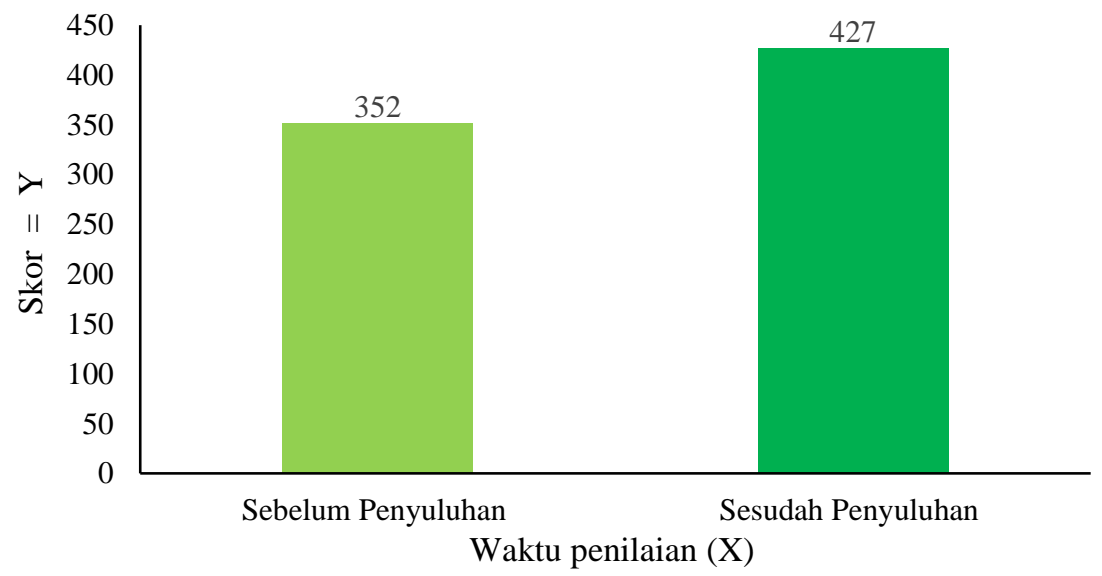

Gambar 3. Skor sebelum dan sesudah pelatihan teknologi budidaya terung ungu di pekarangan

Kondisi ini sama dengan yang terjadi pada KWT Zahra di Kabupaten Tasikmalaya dalam mengadopsi inovasi teknik budidaya tanaman sayuran secara vertikultura. Tingkat kemudahan dalam budidaya vertikultura membuat mereka tertarik dan menimbulkan minat untuk meningkatkan pengetahuan tentang budidaya sayuran secara vertikultura (Isnaeni dan Yunita, 2019).

Hasil penelitian Suryani et al. (2017) menunjukkan bahwa motivasi merupakan salah satu karakteristik individu yang berpengaruh terhadap adopsi inovasi keberlanjutan budidaya tanaman di pekarangan. Sementara karakteristik inovasi yang berpengaruh adalah keuntungan relatif dan kesesuaian inovasi. Hasil penelitian ini mendukung hasil kegiatan PKM di Desa Ciawijapura, di mana para peserta memiliki motivasi untuk melakukan budidaya tanaman terung di pekarangan dengan baik untuk mendukung program pemerintah desa yang menjadikan terung ungu sebagai komoditas unggulannya. Sementara itu, harga jual terung ungu yang cukup tinggi pada saat pelatihan ini dilaksanakan, yaitu sekitar Rp. 8.000,00 per $\mathrm{kg}$, menjadi pendorong para ibu untuk menerapkan hasil pelatihannya.

Kegiatan pendampingan dilaksanakan selama satu bulan, yaitu sampai dengan tanaman tumbuh baik di polybag besar. Berdasarkan kegiatan yang telah dilakukan, para peserta menghendaki keberlanjutan dari program pelatihan ini, dengan materi lain pada komoditas yang sama. Materi yang diusulkan oleh para peserta adalah pengendalian hama dan penyakit pada terung secara organik dan pengolahan buah terung menjadi produk yang layak jual.

\section{KESIMPULAN}

Pelatihan budidaya tanaman terung ungu dalam polybag telah meningkatkan pengetahuan dan keterampilan para anggota TP-PKK dan KWT Al Istiqomah, Desa Ciawijapura. Dampak positif dari meningkatnya pengetahuan ini mendorong para peserta pelatihan untuk mencoba membudidayakan terung ungu dalam polybag dan memeliharanya sesuai dengan materi yang disampaikan pada pelatihan. Implikasi dari kegiatan ini adalah para peserta dapat memanfaatkan lahan pekarangan dengan tanaman yang bermanfaat untuk meningkatkan gizi keluarga. Para peserta berharap keberlanjutan dari kegiatan ini, terutama untuk pengendalian hama dan penyakit secara organik serta penanganan pasca panen dan pengolahan hasil terung.

\section{UCAPAN TERIMA KASIH}

Ucapan terima kasih disampaikan kepada Lembaga Pengabdian kepada Masyarakat (LPM) Universitas Swadaya Gunung Jati (UGJ) yang 
telah membiayai kegiatan ini pada semester ganjil tahun akademik 2019/2020.

\section{DAFTAR PUSTAKA}

Alzarliani, W. O., Mustari, L. O. M., Ajo, A., Hardin, \& Monica, A. A. (2019). Penyuluhan laboratorium lapangan budidaya terong dan cabe di Kelurahan Bandar Batauga Kecamatan Batauga Kabupaten Buton Selatan. Jurnal Pengabdian Masyarakat Membangun Negeri, 3(2), 36-47. https://doi.org/10.35326/pkm.v3 i2.456

Ervina, O., Andjarwati, \& Historiawati. (2016). Pengaruh umur bibit pindah tanam dan macam pupuk daun terhadap pertumbuhan dan hasil tanaman terong (Solanum melongena L.) Varitas Antaboga 1. VIGOR: Jurnal Ilmu Pertanian Tropika dan Subtropika, 1(1), 1222. Tersedia dari https://jurnal.untidar.ac.id/ index.php/vigor/article/view/312

Isnaeni, S., \& Yunita, R. (2019). Adopsi teknologi vertikultur skala rumah tangga pada beberapa jenis sayuran di Desa Parakannyasag, Tasikmalaya. Journal of Empowerment Community, 1(1), 27-32. Tersedia dari https:// www.e-journal.unper.ac.id/index.php/JEC/arti cle/view/179

Miransari, M., \& Smith, D. L. (2014). Plant hormones and seed germination. Environmental and Experimental Botany, 99, 110-121. https://doi.org/10.1016/j.envexpbot. 2013.11.005

Ramadhan, D., Riniarti, M., \& Santoso, T. (2018). Pemanfaatan cocopeat sebagai media tumbuh sengon laut (Paraserianthes falcataria) dan merbau darat (Intsia palembanica). Jurnal Silvia Lestari, 6(2), 23-31. http://dx.doi.org/ 10.23960/js12622-31

Safei, M., Rahmi, A., \& Jannah, N. (2014). Pengaruh jenis dan dosis pupuk organik terhadap pertumbuhan dan hasil tanaman terung (Solanum melongena L.) Varietas
Mustang F1. Jurnal Agrivor, 13(1), 59-66. Tersedia dari http://ejurnal.untag-smd.ac.id/ index.php/AG/article/view/549

Sahid, O. T., Murti, R. H., \& Trisnowati, S. (2014). Hasil dan mutu enam galur terung (Solanum melongena L.). Vegetalika, 3(2), 45-58. Tersedia dari https://journal.ugm.ac.id/ jbp/article/view/5151

Santosa, S. J., \& Sumarni. (2016). Pengaruh konsentrasi ekstrak teh dan macam media terhadap pertumbuhan dan hasil tanaman terong di polybag. Joglo, 28(2), 71-77. Tersedia dari http://ejurnal.unisri.ac.id/index. php/Joglo/article/view/1461

Suryani, A., Fatchiya, A., \& Susanto, D. (2017). Keberlanjutan penerapan teknologi pengelolaan pekarangan oleh wanita tani di Kabupaten Kuningan. Jurnal Penyuluhan, 13(1), 50-63. https://doi.org/10.25015/penyu luhan.v13i1.14641

Thoriqussalam, A., \& Damanhuri. (2019). Pengaruh komposisi media pesemaian terhadap pertumbuhan dan produksi bawang merah asal biji (True Shallot Seed). Jurnal Produksi Tanaman, 7(7), 1314-1321. Tersedia dari http://protan.studentjournal.ub. ac.id/index.php/protan/article/view/1180

Umarie, I., Wijaya, I., \& Suhdi. (2019). Kombinasi media tumbuh meningkatkan pertumbuhan dan hasil tanaman terong (Solanum melongena L.) pada budidaya hidroponik duck bucked system. Gontor AGROTECH Science Journal, 5(2), 127-149. http://dx.doi.org/10.21111/agrotech.v5i2.3389

Waskito, K., Aini, N., \& Koesriharti. (2017). Pengaruh komposisi media tanam dan pupuk nitrogen terhadap pertumbuhan dan hasil tanaman terong (Solanum melongena L.). Jurnal Produksi Tanaman, 5(10), 1586-1593. Tersedia dari http://protan.studentjournal.ub. ac.id/index.php/protan/article/view/545 